\title{
The Mousterian lithic assemblage of the Ciota Ciara cave (Piedmont, Northern Italy): Exploitation and conditioning of raw materials
}

\author{
Sara Daffara ${ }^{1}$, Marta Arzarello ${ }^{1,2}$, Gabriele L.F. Berruti ${ }^{1,3}$, Giulia Berruto ${ }^{1}$, \\ Davide Bertè ${ }^{1,4}$, Claudio Berto ${ }^{2}$, Anna I. Casini ${ }^{2}$ \\ 1. Associazione culturale "3P - Progetto Preistoria Piemonte", San Mauro Torinese (TO), Italy. \\ 2. Università degli Studi di Ferrara, Dipartimento Studi Umanistici, LT TekneHub, Ferrara, Italy. \\ 3. Department of Geology - UTAD Universidade de Trás-os-Montes e Alto Douro, Vila Real, Portugal. \\ 4. Università "Sapienza" di Roma, Rome, Italy. \\ Email: Arzarello: rzrmrt@unife.it; Daffara: saradaffara@virgilio.it; Berruti: gabrielelf.berruti@gmail.com; \\ Berruto: giulia.berruto@yahoo.com; Bertè: dvb83@libero.it; Berto: claudio.berto@unife.it; \\ Casini: annailiac@yahoo.com
}

\begin{abstract}
:
The Ciota Ciara cave is situated in Monte Fenera's karst (Borgosesia - Vercelli), at 670 metres above sea level. It is the most important evidence of a Middle Palaeolithic settlement in Piedmont: the cave was used by Homo neanderthalensis during the OIS 5, in a mild-humid period, as proven by faunal remains. The environment was characterized by deciduous woodland and glades. The intersection between different habitats, the presence of lithic raw materials, the karst morphology and water sources were certainly the main factors that encouraged human settlement during the Upper Pleistocene period, between 80.000 and $70.000 \mathrm{BP}$.

In 2009 systematic excavations began in the cave by the University of Ferrara, in partnership with the Soprintendenza per $i$ Beni Archeologici del Piemonte e del Museo di Antichità Egizie. Research focused on the cave's atrium where three stratigraphic units were investigated: 13, 103 and 14.

The exploited raw materials' characterization were made by the stereo-microscope observations and through the SEM (Scanning Electron Microscope). Several lithologies are represented in different proportion: quartz is the predominant exploited raw material, followed by spongolite, sandstone, mylonite and opal. The archaeological record consists of various typologies of quartz: macrocrystalline pegmatite quartz, micro-crystalline pegmatite quartz and hyaline quartz. All these types of raw materials have been found in the proximity of the archaeological site, within $5 \mathrm{~km}$ range.

The lithic assemblage is made of flakes, retouched tools, cores and debris. The raw materials exploitation was achieved through the direct percussion technique with various methods: S.S.D.A., discoid and Levallois. The reduction sequences on quartz are complete, although no refitting was found. The reduction sequence is not complete for most part of the other raw materials. The débitage products are small-medium size $(1-4 \mathrm{~cm})$ and have different morphologies.

The use-wear analysis on quartz's artefacts was carried out using the low power approach. The preservation state of the lithic assemblage is very good and no chemical, mechanical or post-
\end{abstract}

Published by the School of History, Classics and Archaeology, University of Edinburgh ISSN: 2055-0472. URL: http://journals.ed.ac.uk/lithicstudies/

This work is licensed under a Creative Commons Attribution 2.5 UK: Scotland License. 
depositional alterations are evident. The use-wear analysis shows a predominance of medium-hard and medium-soft materials processing.

The lithic industries characteristics show the production strategies adaptation typical of the Middle Palaeolithic to the characteristics of the non-sedimentary raw materials.

Keywords: Mousterian; Ciota Ciara; quartz; lithic technology; supply areas; use-wear analysis

\section{Introduction}

The Ciota Ciara cave is located in Piedmont, Monte Fenera's karst, an isolated relief in north-western Italy, at 670 metres above sea level (Figure 1). It is an active karst cave developed over more than 80 metres on its principal axe. The cave is situated in the West side of Monte Fenera and, in addition to other caves of the mount, represents one of the most important and complete evidences of the Piedmont Palaeolithic.

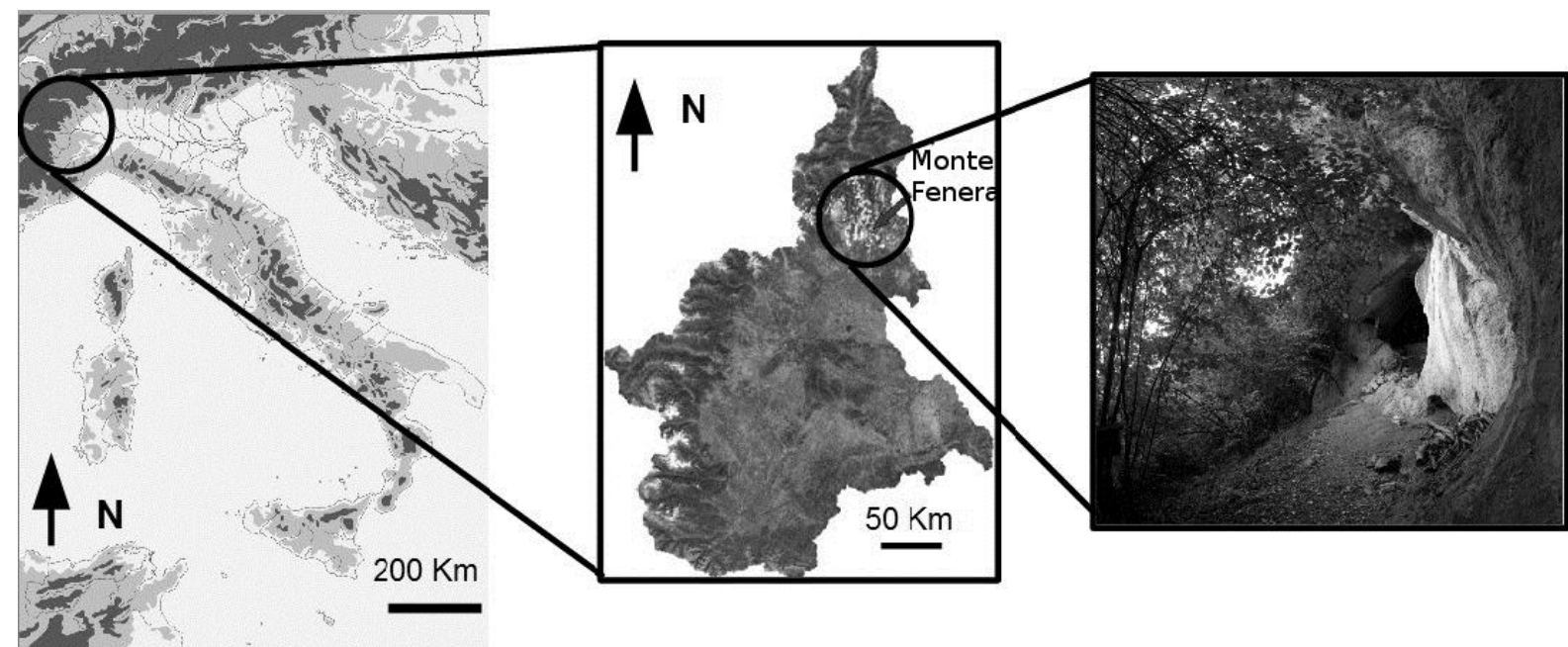

Figure 1. Left and centre: location of Monte Fenera and the Ciota Ciara cave. Right: photo of the Ciota Ciara cave by P. Ottaviano.

The first investigations, with a naturalistic intent, were carried out on Monte Fenera in the second half of the nineteenth century but the real research at the Ciota Ciara cave wasn't started until the post-war period. Over more than 30 years, several excavations were directed by numerous researchers, in particular by Francesco Fedele from the Anthropology Institute of the University of Turin who excavated in the Ciota Ciara and in other caves of Monte Fenera from 1966 until 1978 (Fedele 1966; 1984-85; Strobino 1992; Busa et al. 2005).

At the end of the 1970s, research at the Ciota Ciara cave was discontinued but restarted in the 1990s, for 3 years, with the scientific direction of the Soprintendenza per $i$ Beni Archeologici del Piemonte e del Museo di Antichità Egizie (Busa et al. 2005).

In 2009 systematic excavations at the Ciota Ciara cave were restored, once again, by the University of Ferrara in partnership with the Soprintendenza per i Beni Archeologici del Piemonte e del Museo di Antichità Egizie. After a restoration of the previous excavations, the new researches were focused, principally, in the cave atrium, where were investigated three stratigraphic units: 13, 103 and 14 (Figure 2).

The three stratigraphic units have a horizontal disposition and are characterized by a reddish-brown clay-sand matrix with rare and altered centimetre-sized pebbles, more frequent in S.U.14. The stratigraphic units highlighted are extended over the whole area investigated (8 $\mathrm{m}^{2}$ ), with the exception of the S.U.103 localized, exclusively, in an area of about $50 \mathrm{~cm}^{2}$, probably as a result of the water percolation in the area along the rock wall. The spatial 
distribution analysis of lithic and faunal remains did not enable us to actually identify any particular spatial organization, probably due to the restricted area of investigation (Arzarello et al. 2012a; 2012b) (Figure 3).
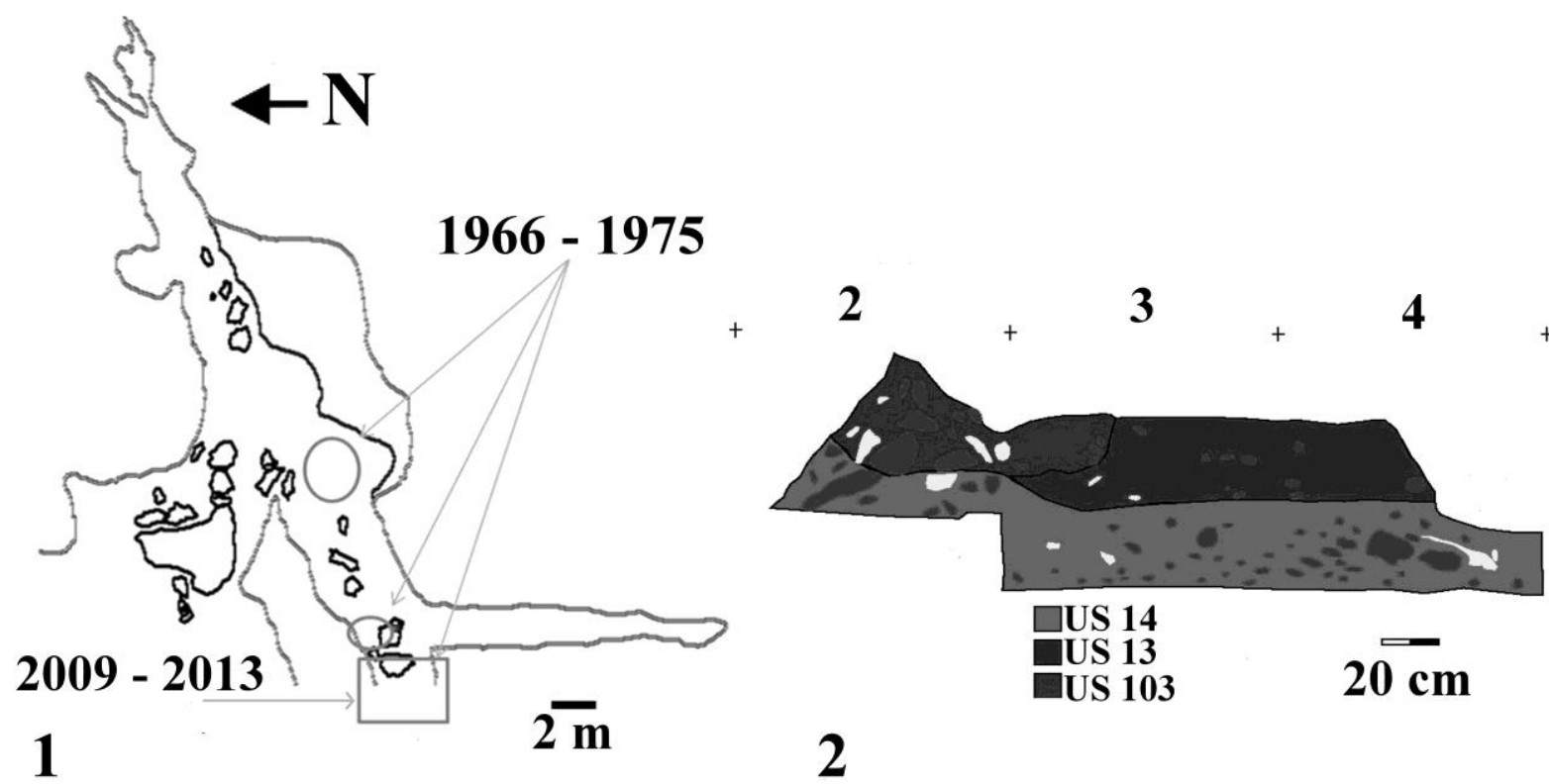

Figure 2. 1. Planimetry of the Ciota Ciara cave. 2. Longitudinal section G/F.

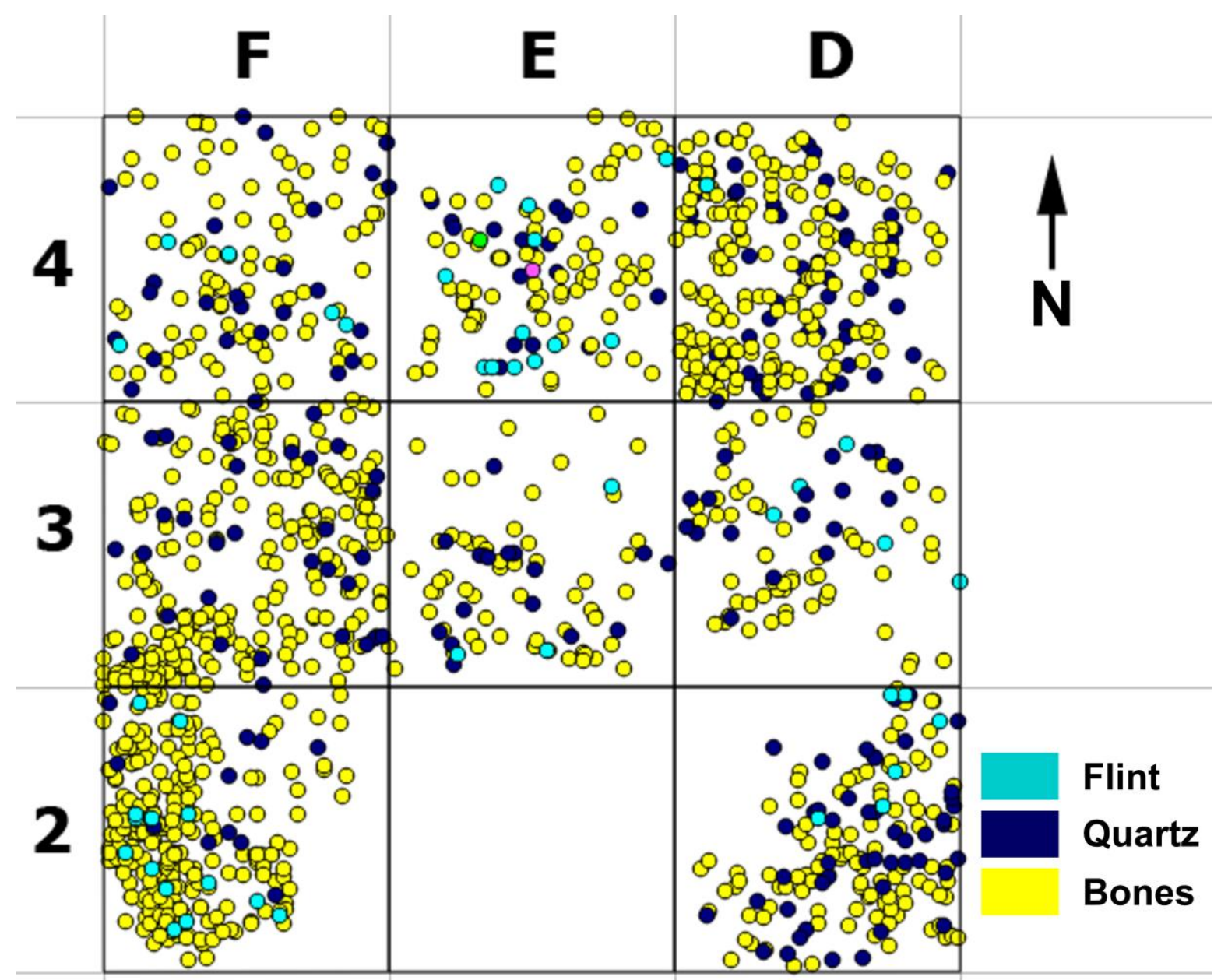

Figure 3. The Ciota Ciara cave spatial distribution of coordinate objects from the SU 14 (excavation 2013). 1 metre grid. 


\subsection{Palaeo-environmental reconstruction}

The palaeo-environmental reconstruction has been achieved through the faunal analysis.

The macro mammals analysis was carried out on the remains coming from S.U.13 and 103. The total number of the remains is 1.620 of which $40 \%$ is not determinable from a taxonomical point of view. The faunal assemblage is characterized by: Ursus spelaeus, Ursus arctos, Canis lupus, Vulpes vulpes, Meles meles, Lynx lynx, Panthera leo, Panthera pardus, Rupicapra rupicapra, Cervus elaphus, Bos sp., Bos vel Bison, Stephanorhinus sp.and Hystrix sp.. The presence of herbivores in S.U.13 and 103 is numerically not representative $(3,8 \%$ of determinable remains) but, even if no detailed analysis in the S.U. 14 has been made, it appears clear a significantly increase of the herbivorous remains $(8,9 \%$ of determinable remains). The genus Ursus is the most abundant taxon found: $60 \%$ of determinable remains in levels 13 and 103, and 57\% in level 14. The family Ursidae is represented by two species: $U$. spelaeus and $U$. arctos. The continuous presence of the cave bear is diagnostic that the deposit is former 28ka, because likewise this species disappears from the Alps. The presence of some faunal remains like Cervus elaphus, Lynx lynx and Meles meles suggests the existence of a deciduous woodland and the incidence of Hystrix is typical of a warm climate (Arzarello et al. 2012a; 2012b).

The small mammals' association from the Ciota Ciara cave (S.U. 13, 103 and 14) gives some information about the environment that surrounded the site and made it possible to establish the chronology of the site.

Species living in woodland environments are dominant: Myodes glareolus is the most frequent rodent, afterwards followed by another taxon living in woodland, Apodemus (Sylvaemus), represented by two species, A. (S.) sylvaticus and A. (S.) flavicollis. Less frequent in the assemblage, have been identified species typical of open grassland like Microtus arvalis. The presence of warmer indicators (i.e. Erinaceus europeus and Histrixsp.), together with mammals that live in closed environments, and the existence of Pliomys coronensis $(=P$. lenki; priority discussed by Terzea, 1983) allow a calibration of the site into a temperate period of OIS 5 (OIS $5 \mathrm{c}$ or 5a), even if not available a radiometric dating yet (Arzarello et al. 2012a; 2012b).

\section{Materials and methods}

The analysis of the lithic assemblage of the Ciota Ciara cave consists of a multidisciplinary study involving the study of the supply areas, the techno-typological and the use-wear analysis. The lithic assemblage is composed by 498 finds from S.U. 13 and 103 and by more than 4,000 finds from S.U. 14. The study of the S.U. 13 and 103 is complete, while the lithic assemblage from S.U.14 is still going on.

The study of the supply areas has been performed on the lithic remains coming from levels 13 and 103 and it has been carried out in several phases: the discovery of the raw materials outcrops in the proximity of the archaeological site; the cataloguing of the rock outcrops and their GPS tracking; the specimen of the raw material and the characterization of the exploited raw materials by stereo-microscope observations and, where necessary, through the use of a SEM (Scanning Electron Microscope) (Arzarello et al. 2012a; 2012b).

In order to carry out a study of the supply areas, it is important perform a careful analysis of the raw materials available in the area; therefore it is basic have a good knowledge of the geology of the region (Arzarello et al. 2011).

Monte Fenera is situated near the connection area between the Po Valley in subsidence and the rising Alpine chain (Fantoni et al. 2005a); the external areas of the chain, such as these, starting from the Oligocene (about $30 \mathrm{Ma}$ ) were affected by a compressive deformation with a general high level rising. Minor structures, related to this system of lithospheric fault, 
are fragile sectors that were activated in different periods, affecting the present physiographic and geological structure of the area (Fantoni et al. 2005a).

The base of Monte Fenera consists of Hercynian metamorphic rocks (ortogneiss, paragneiss and micaschist) belonging to the sub-units of Scisti dei Laghi, while on the northern, western and southern sides of the mountain there is a Permian formation extending throughout the surrounding area (Strobino, 1981). Subsequently the Mesozoic sedimentary rocks: a Triassic's sequence composed of sandstone, followed by the Dolomia di San Salvatore (i.e. a thick dolomitized carbonate series within which the karst system is developed) (Strobino 1981; Fantoni et al. 2005b); on that, there is the Jurassic's sequence, made of sandstones and rubble-stones and, subsequently, at the top of the mount, a spongolitic limestones sequence (Strobino 1981; Fantoni et al. 2005b).

The techno-typological analysis was carried out on the lithic assemblage of S.U. 13 and 103 while the data of S.U. 14 are still uncomplete. The identification of the technique employed for the exploitation of the lithic raw materials is based on the criteria listed by Inizan et al. (1995). The definition of the knapping methods are based on Forestier (1993) for the S.S.D.A. method (i.e. Système par surface de débitage alterné) and on Boëda (1993; 1994) concerning Levallois and Discoid knapping methods. The typological analysis is based on Bordes (1961).

The use-wear analysis was carried out on the lithic assemblage of S.U.13 combining the Low Power Approach (Semenov 1954) and the High Power Approach (Keeley 1980).

The identification of the worked materials' hardness was made according with Odell's classification (Odell 1981).

The low-magnification analysis was carried out using a Seben Incognita 3 (10-80x) stereo microscope and a Dinolight Am413T (5-230x) digital microscope. The highmagnification analysis was made using a AmScope ME300T-M (40-640x) metallographic microscope, equipped with an AmScope MD600 camera. The traces' presence recognized on the surface of the lithic tools is referred to in the scheme by Van Gijn (1989) and modified by Berruti (Berruti \& Arzarello 2012).

In order to perform a correct analysis of the lithic assemblage, it has been necessary making an experimental collection, using all the lithic raw materials identified in the archaeological record. During the experimental activity the following operations were performed: skinning and butchering of a wild boar; processing of skin, bone and wood. By comparing the use-wear traces of quartz and flint tools, it was possible to point out how quartz tools are effective for processing soft and medium-soft materials, while being less suitable for the processing of hard materials.

The reason of such a different mechanical response is due to the high fragility of the edges that dramatically limits their use, especially during the processing of the hardest materials. The spongolite tools have poor mechanical property too. The crystals' particular morphometry, that forms the macro-crystalline pegmatite quartz, makes the highmagnification analysis of the lithic tools with this kind of raw material very difficult. This is due to the micromorphology of the surfaces that does not allow to bring into focus using the metallographic microscope (Berruti \& Arzarello 2012; Sussman 1985). As indicated in literature, the lithic tools in hyaline quartz do not have the same problems because they have regular surfaces (Pignat \& Plisson 2000; Berruti \& Arzarello 2012; Sussman 1985).

\section{The lithic assemblage}

\subsection{Supply areas}

The archaeological record's analysis of the Ciota Ciara cave (S.U. 13 and 103) shows that many lithologies are represented (Figure 4). Quartz is the prevalent exploited material 
$(83,18 \%)$, followed by spongolite $(15,89 \%)$, sandstone $(0,56 \%)$, mylonite $(0,19 \%)$ and opal $(0,19 \%)$. Concerning the quartz, many typologies are represented: macro-crystalline pegmatite quartz, micro-crystalline pegmatite quartz and hyaline quartz.

\section{Sandstone; $0.56 \%$ Milonite; $0.19 \%$ Opal; $0.19 \%$}

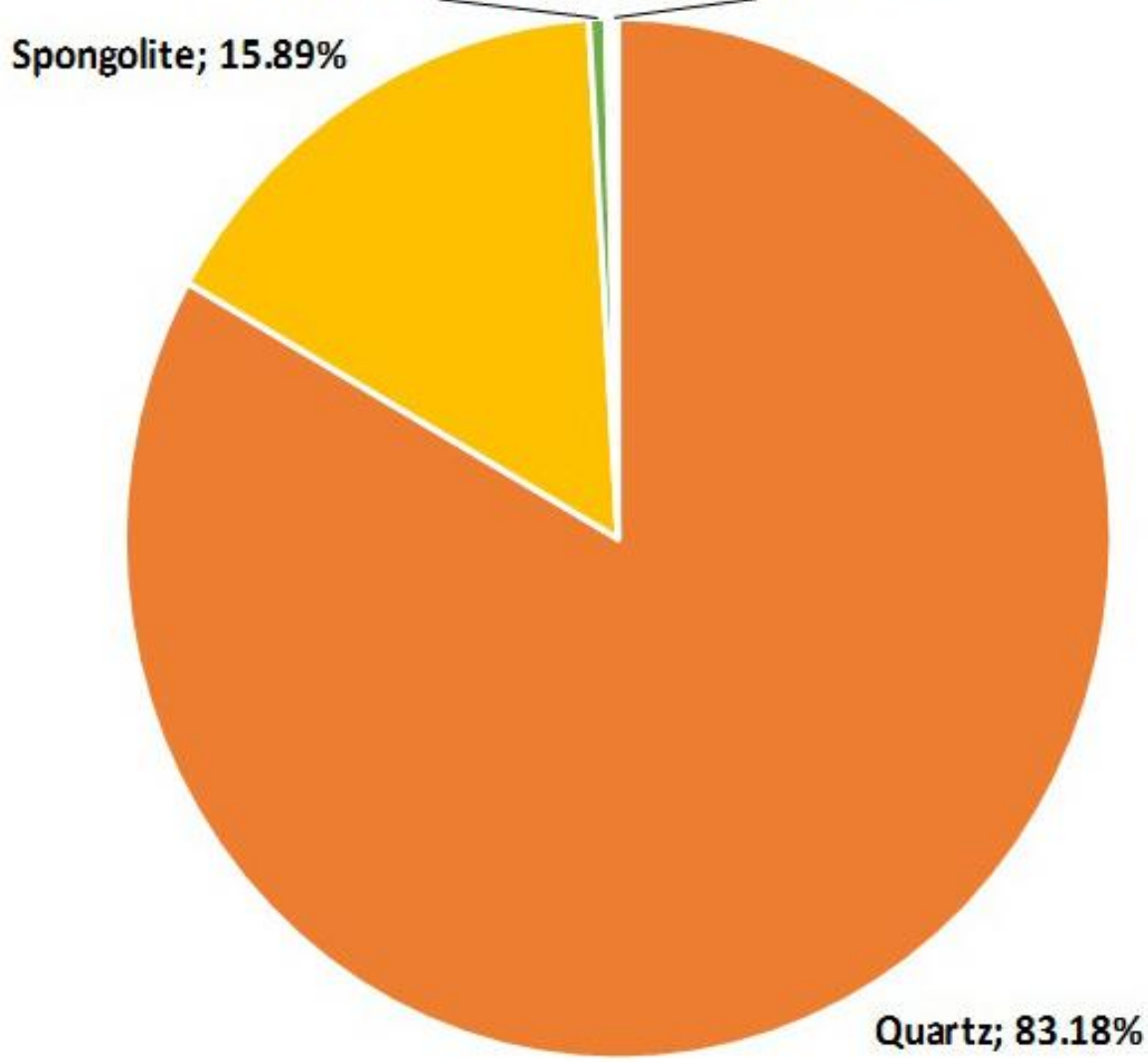

Figure 4.Graph showing the lithologies identified within the archaeological record at the Ciota Ciara cave, S.U. 13 and 103.

The quartz outcrops are concentrated, mainly, at te base of Monte Fenera, in hydrothermal veins, within both the Permian volcanic rocks and the Hercynian metamorphic rocks, besides being present, in a secondary position, as pebbles within rivers and Pliocene deposits. Spongolite is the most exploited raw material, right after quartz. It is represented by different typologies, more or less porous and silicified. Spongolite crops out in the highest part of the mountain, within the spongolitic limestones. Opal and mylonite have been found only in secondary position, between 50 and 450 metres away from the site.

The use of sandstone pebbles as hammers is also confirmed in the lithic assemblage: sedimentary rocks were readily available in the area, sometimes as an insertion within the spongolitic levels.

All the lithologies found in the archaeological record are present on Monte Fenera and, probably, they have been collected within a maximum range of $5 \mathrm{~km}$ from the site (Figure 5).

Reasonably, the human groups that occupied the Ciota Ciara cave, during the Middle Palaeolithic, collected lithic raw materials on Monte Fenera within a range of few kilometres (less than $1 \mathrm{~km}$ for spongolite, sandstone, mylonite and opal, and about $2.5 \mathrm{~km}$ for quartz), since the area is characterized by the lithologies represented in the archaeological record (Arzarello et al. 2012a; 2012b).

The extent of the supply areas recognised is completely coherent with the considered chronological period (Cliquet 2007; Depaepe 2007; Huet 2007). 


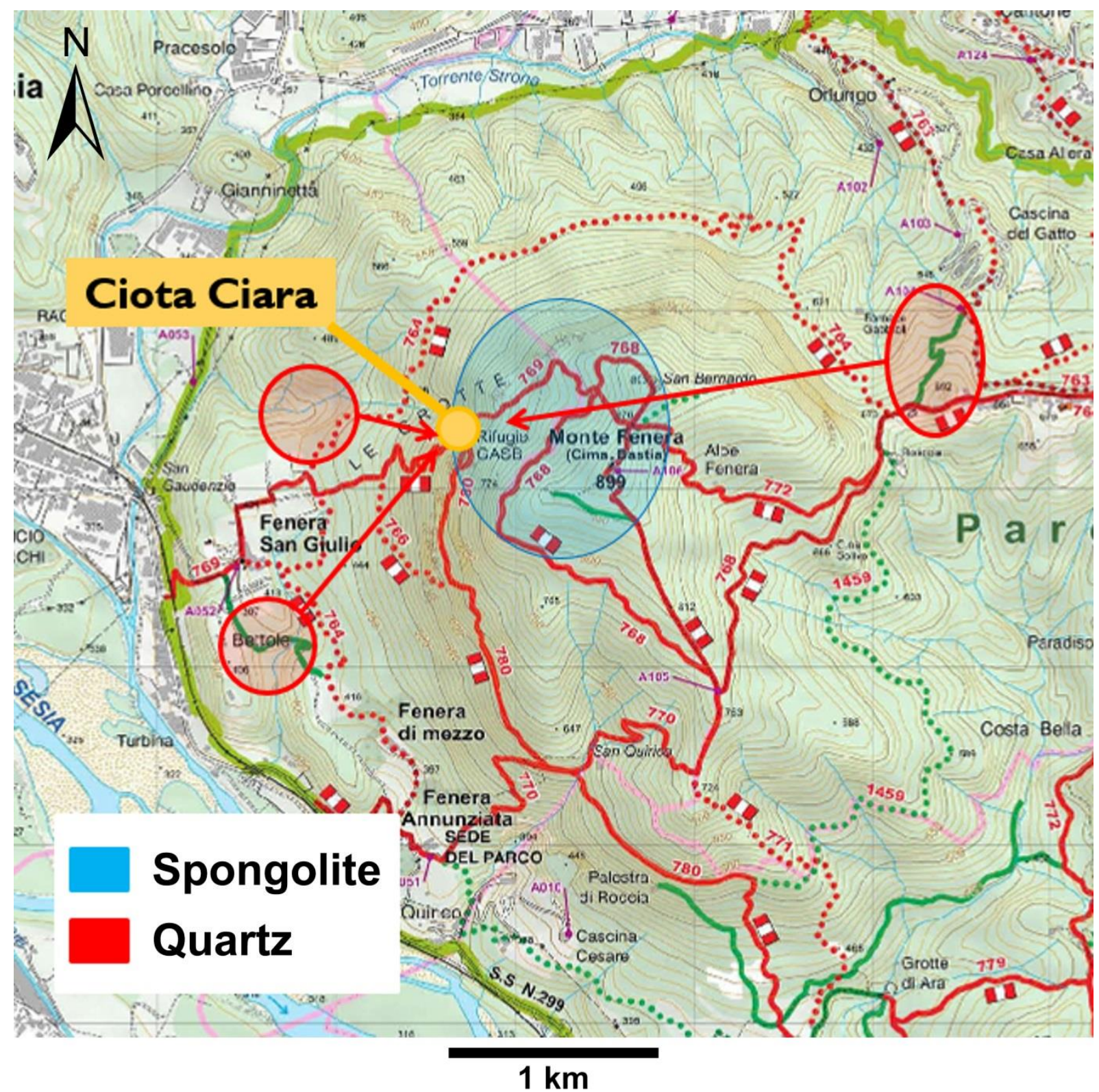

Figure 5. Map of the area around Monte Fenera with the supply areas location of quartz and spongolite.

The management of different raw materials, within the archaeological site, is sometimes related to the distance required to be covered for their collection (Depaepe 2007; Huet 2007; Vaquero 2007): usually the frequency of a lithology, in the archaeological record, is inversely proportional to the distance of its supply area (Depaepe 2007). "Exotic" raw materials are generally employed for the most complex knapping methods, while the local raw materials are often exploited with opportunistic knapping methods (Depaepe 2007; Huet 2007; Vaquero 2007).

Regarding the Ciota Ciara cave, the comparison between techno-typological data and those on the supply areas has not provide any evidences for differential management of raw materials, in relation to the débitage methods. Moreover, quartz is the dominant lithology in the archaeological record, although its worst débitage aptitudes and its bigger distance from the site. This could be attributed to the spongolite that is frequently fractured and, consequently, probably unusable (Arzarello et al. 2012a; 2012b). On the other hand, the latest excavations suggest that the importance of allochthonous flint is increasing and that the blanks were introduced within the site in the form of pre-cores or big flakes. 


\subsection{Technological analysis}

Because of the characteristics of the raw materials, the opportunistic knapping methods are predominant within the lithic assemblage (Table 1) and the number of débris, fractures and knapping errors, almost all definable as Syret accidental break, is very high. The term Syret is used in a broader sense to indicate any kind of fracture, contemporary to the débitage, having as a starting point the flake impact point and leading to its breaking in two or more parts on the longitudinal axe (Mourre 1996).

Table 1. Ciota Ciara cave. Technological analysis performed for S.U. 13, 103 and 14.

\begin{tabular}{|c|c|c|c|}
\hline & S.U. 13 & S.U. 103 & S.U. 14 \\
\hline S.S.D.A. & $\begin{array}{l}\text { Flakes: } 281 \\
\text { Cores: } 20\end{array}$ & $\begin{array}{l}\text { Flakes: } 17 \\
\text { Cores: - }\end{array}$ & $\begin{array}{l}\text { Flakes: } 470 \\
\text { Cores: } 21\end{array}$ \\
\hline Levallois & $\begin{array}{l}\text { Flakes: } 2 \\
\text { Cores: } 2\end{array}$ & $\begin{array}{l}\text { Flakes: - } \\
\text { Cores: - }\end{array}$ & $\begin{array}{l}\text { Flakes: } 5 \\
\text { Cores: } 3\end{array}$ \\
\hline Discoid & $\begin{array}{l}\text { Flakes: } 11 \\
\text { Cores: } 4\end{array}$ & $\begin{array}{l}\text { Flakes: - } \\
\text { Cores: - }\end{array}$ & $\begin{array}{l}\text { Flakes: } 8 \\
\text { Cores: } 4\end{array}$ \\
\hline Kombewa & $\begin{array}{l}\text { Flakes: } 3 \\
\text { Cores: - }\end{array}$ & $\begin{array}{l}\text { Flakes: - } \\
\text { Cores: - }\end{array}$ & $\begin{array}{l}\text { Flakes: - } \\
\text { Cores: } 3\end{array}$ \\
\hline Debris & 179 & 18 & 264 \\
\hline
\end{tabular}

Direct percussion by hard hammer is the only technique employed, while the methods are various: opportunistic/S.S.D.A. (Forestier 1993), Levallois and discoid (Boëda 1993; 1994).

Quartz was exploited using all these knapping methods, while spongolite, in S.U.13, was knapped using only opportunistic/S.S.D.A.débitage, probably depending on both its internal fractures and the morphology of the pebbles. In S.U. 14 the discoid method is used also for the spongolite exploitation.

In the Mousterian levels of the Ciota Ciara cave the use of fossil bones for the production of tools is also evident: a denticulate and a side-scraper come, respectively, from S.U. 13 and 14 , while another denticulate was discovered during the 2009 excavation, within rehashed sediments (Figure 6).

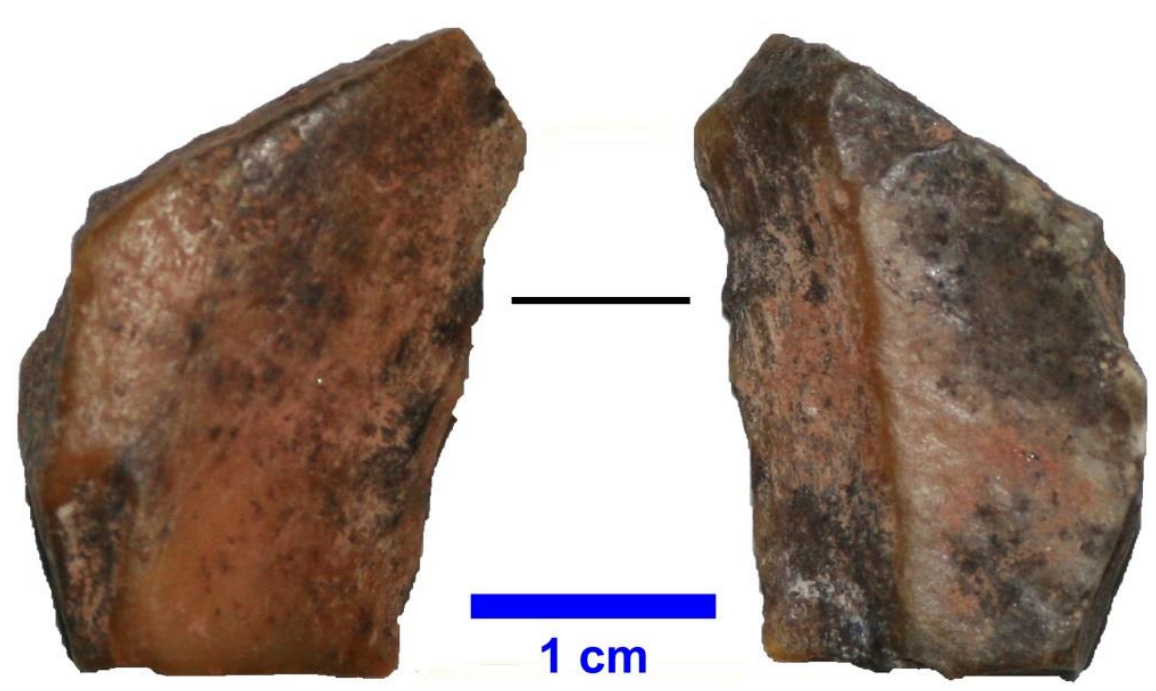

Figure 6.Bone side-scraper from the Ciota Ciara cave. The scale bar is $1 \mathrm{~cm}$ wide. 
This organic raw material has been exploited in the same way as the lithic raw material: on the edge of the tools are evident the marks of direct percussion by hard hammer.

The S.S.D.A. method has been employed to produce irregular and non-standardized flakes, all characterized by the presence of, at least, one cutting edge (Arzarello et al. 2012b). The huge number of natural butts and cortical flakes, together with the predominance of unipolar removal negatives on the flakes' dorsal face, suggest a first stage of débitage consisting in the exploitation of a natural convexity of the pebble by removing a cortical flake, followed by the removal of other flakes using the same striking platform until the exhaustion of the natural convexity.

The Levallois method was employed to produce artefacts with convergent edges or Levallois points and only two forms of this method are represented: recurrent centripetal and lineal (Boëda 1994). This knapping method was used only on pebbles with suitable natural convexities, in order to minimize the shaping out of the core (Figure 7). The lineal Levallois débitage is most used although the shaping out of the core is more difficult and expensive, in terms of raw material, compared with the recurrent Levallois methods. This choice is linked to the quartz characteristics that is problematic to manage with recurrent knapping methods, because of the knapping errors frequency.
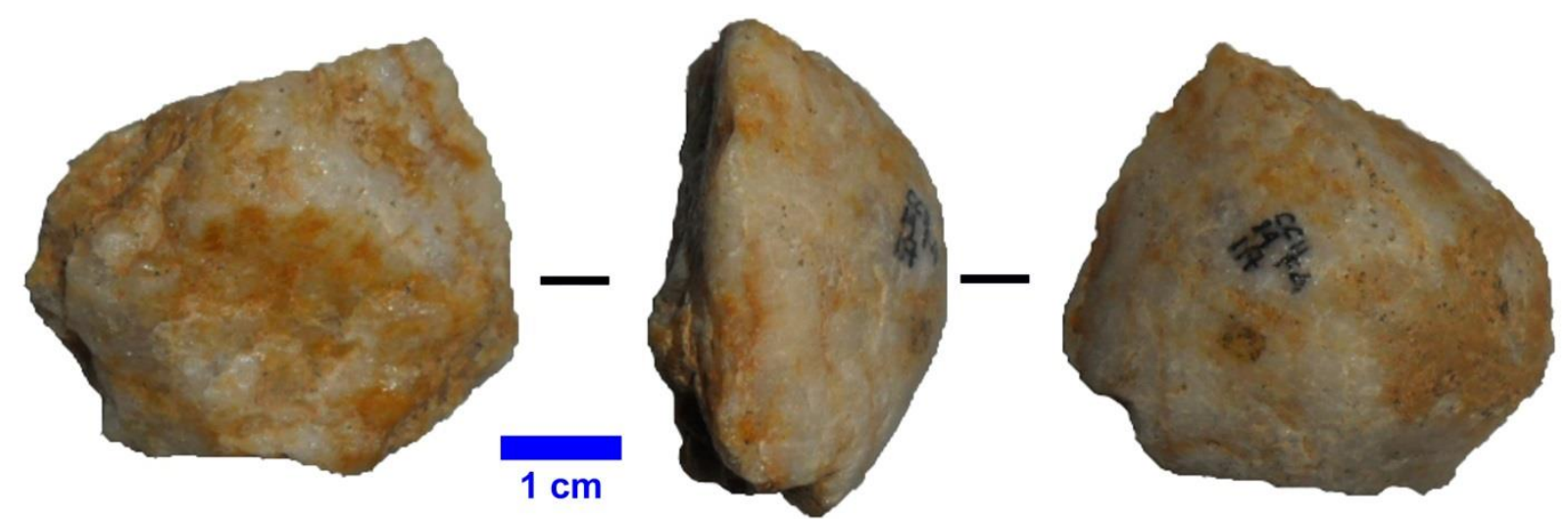

Figure 7. Levallois core with cortical striking platform from the Ciota Ciara cave. The scale bar in the image is 1 $\mathrm{cm}$ wide.

The discoid method (Boëda 1993) is represented by both bifacial and unifacial mode, depending on the more or less spherical morphology of the cores (Arzarello et al. 2012a; 2012b). The core's shaping out does never come first the stage of plein débitage: the discoid exploitation begins from the natural surface of the pebbles and continues through the detachment of debordant flakes, in order to preserve and manage the core's convexities. The discoid products have quadrangular or triangular shapes and are characterized by an important thickness in the proximal part. The debordant flakes often have the typical morphology of a pseudo-Levallois point (Arzarello et al. 2012b) (Figure 8).

Sometimes large flakes were used as cores. This kind of exploitation, although referred to a Kombewa s.l. knapping method (Owen 1938), has as its purpose the reduction of the technical investment and the maximum exploitation of the raw material.

The lacking number of retouched tools reveals a further adaptation to the characteristics of the raw materials: the retouch on quartz flakes is quite difficult and it does not permit to obtain stronger or more useful edges, compared to the unretouched (Mourre 1996). Among the retouched tools, most of them are side-scrapers, lateral or convergent, followed by denticulates and notches (Figure 9.)

The reduction sequences, especially those S.S.D.A., are short and rarely reach the full exploitation of the cores (Figure 10). 


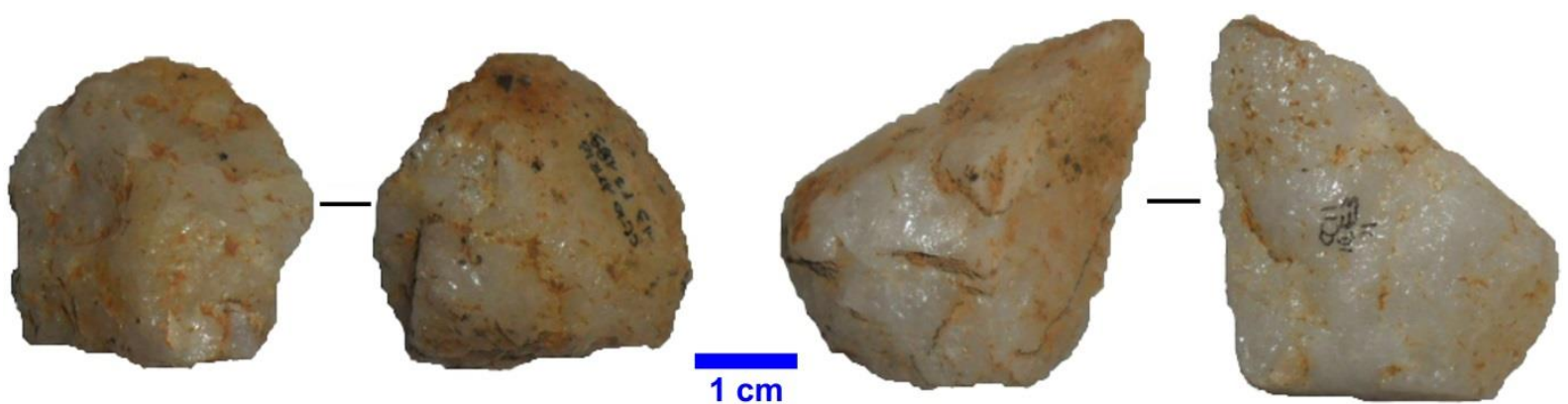

Figure 8.Discoid core (on the left) and side-scraper on pseudo-Levallois point (on the right) from the Ciota Ciara cave. The scale bar in the image is $1 \mathrm{~cm}$ wide.
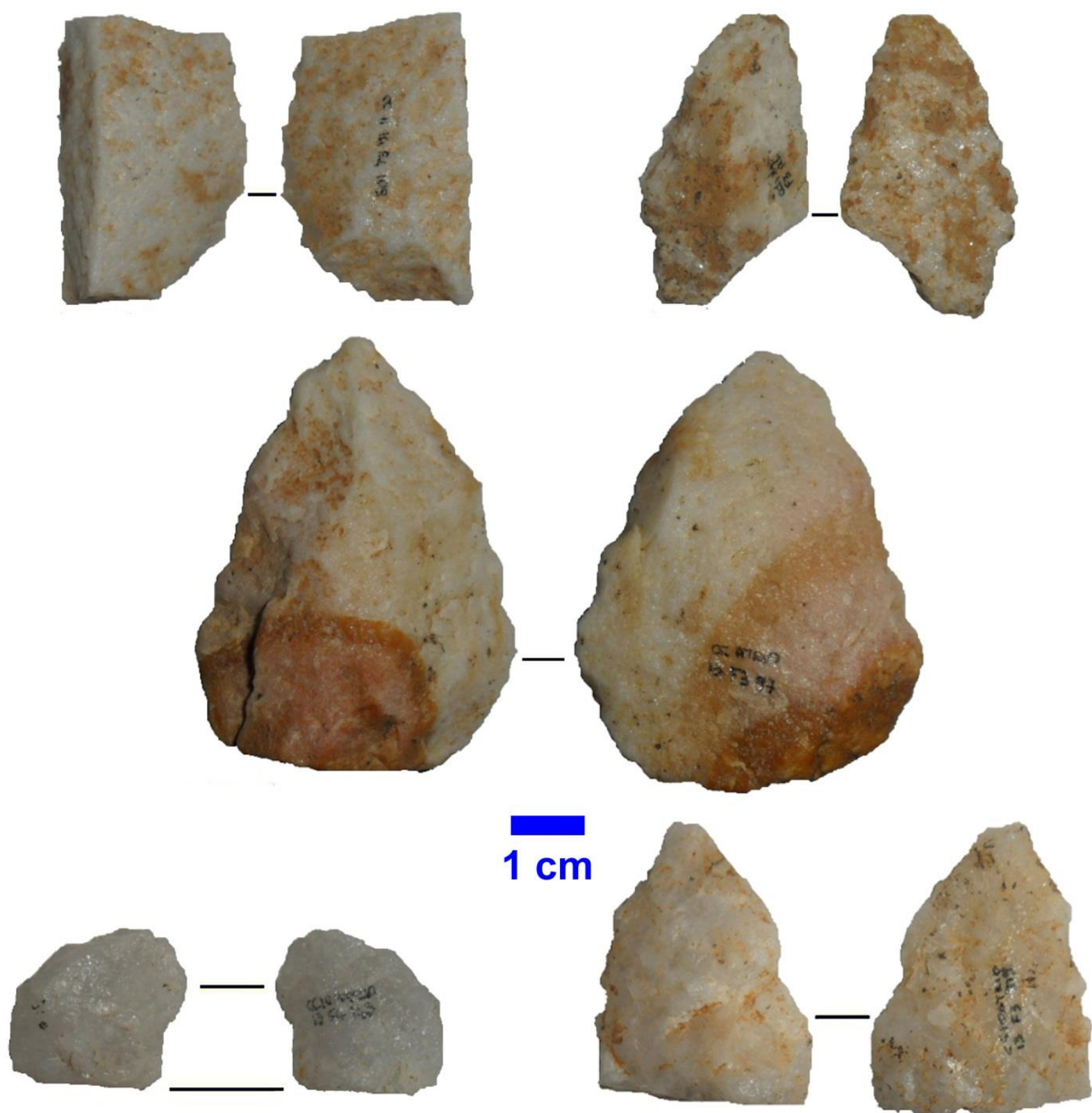

Figure 9. Retouched tools from the Ciota Ciara cave. Side-scraper and double side-scraper (top); Mousterian point (middle); notch and side-scarper (bottom). The scale bar in the image is $1 \mathrm{~cm}$ wide.

Levallois and discoid cores never show more than one phase of exploitation. This is probably due to the easy availability of the raw material, to the minimum dimensions required 
for the knapping products, to the characteristics of quartz that breaks easily during the débitage.
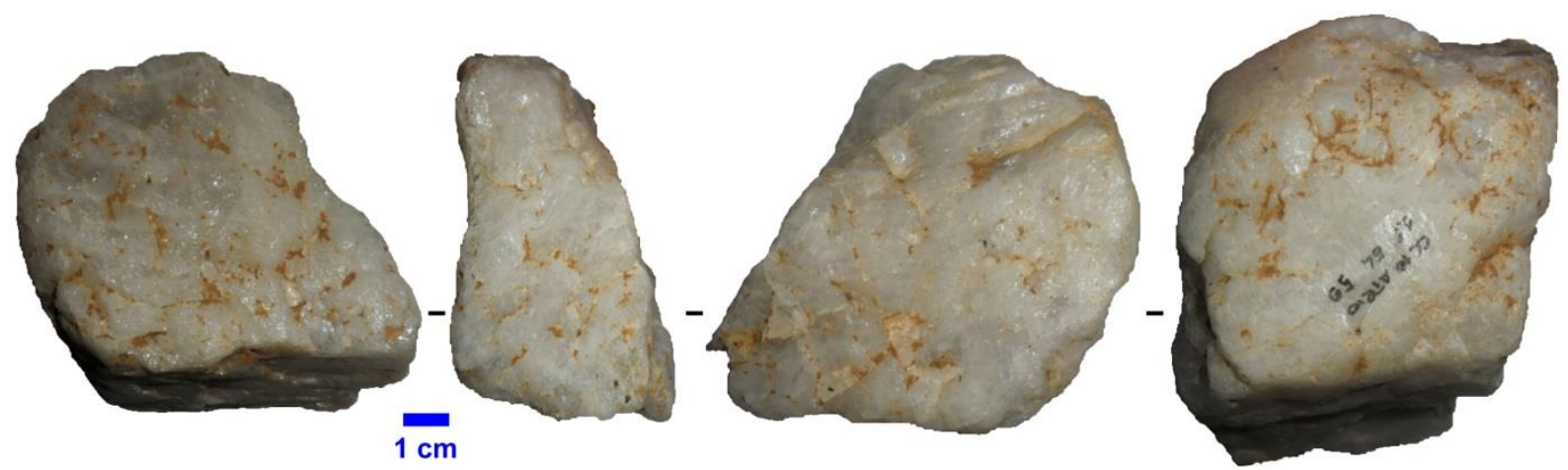

Figure 10. The Ciota Ciara cave. S.S.D.A. Core. The scale bar in the image is $1 \mathrm{~cm}$ wide.

Although no refitting has been found, because of the raw material characteristics and the presence of a huge number of fractures, the reduction sequences on quartz are complete: definitely the quartz exploitation has been carried out within the site. This does not apply to the siliceous rocks, as these have fragmentary reduction sequences that may reflect several factors: the management of one or more phases of the reduction sequence outside the excavated area or the import, within the cave, of finished tools (Arzarello et al. 2012a; 2012b).

\subsection{Use-wear analysis}

Almost all the quartz artefacts of S.U. 13 are made of local macro-crystalline pegmatite quartz, while two of them are made of micro-crystalline pegmatite quartz. Furthermore, in the lithic assemblage 43 small artefacts in hyaline quartz are also present: large, bright and transparent crystals, at times, make up the kind of macro-crystalline pegmatite quartz exploited in the Ciota Ciara cave and, probably, the artefacts classified as "hyaline quartz artefacts" can be attributed to the knapping of a single crystal of macro-crystalline pegmatite quartz.

The state of conservation of the lithic assemblage is relatively good and no chemical (white patina, bright spots) nor mechanical (soil sheen, trampling) post-depositional alterations are evident.

The use-wear analysis was performed for all the retouched tools, while among the unretouched flakes have been selected those with the following characteristics: presence of functional edges, absence of fractures and of evident post-depositional alterations. According to these criteria, 130 artefacts (124 on local quartz and 6 on spongolite) have been chosen for the use-wear analysis and 13 quartz artefacts show use-wear traces (Table 2).

There are four tools with use-wear traces: a bi-convex convergent side-scraper on Levallois point (i.e. Mousterian point); a side-scraper; a bi-convex convergent side-scraper; a notch plus a denticulate. On the Mousterian point have been identified two different areas of use, referable to a transversal action on medium-hard materials (Figure 11); the side-scraper shows one zone of use attributable to a transversal action on hard material; the notch plus a denticulate presents the typical traces of a longitudinal action on medium-soft material, while on the bi-convex convergent side-scraper has been identified an impact fracture.

Among the unretouched flakes, 118 were selected for the use-wear analysis (111 on quartz and 7 on spongolite). Nine quartz unretouched flakes show use-wear traces and on just one of them have been identified two different zones of use. Regarding the nature of actions 
observed, the presence of one flake with use-wear traces relating to the perforation of medium-hard material is quite remarkable.

Table 2. Ciota Ciara cave. Results of the use-wear analysis performed on the artefacts of S.U. 13. The position of the traces identified is referred to the scheme made by Van Gijn (1989) and modified by Berruti (Berruti \& Arzarello 2012). Action: $\mathrm{T}=$ Transversal; $\mathrm{P}=$ Perforation; $\mathrm{L}=$ Longitudinal; $\mathrm{I}=$ Impact. Worked materials: $\mathrm{H} .=$ Hard; M.H. = Medium hard; S. = Soft; M.S. = Medium soft. The retouched tools are highlighted.

\begin{tabular}{|c|c|c|c|c|c|c|c|c|}
\hline Tool & $\begin{array}{c}\text { Raw } \\
\text { material }\end{array}$ & $\begin{array}{l}\text { Zones } \\
\text { of use }\end{array}$ & $\begin{array}{c}\text { Zone of } \\
\text { use 1: } \\
\text { position }\end{array}$ & $\begin{array}{c}\text { Zone } \\
\text { of use } \\
1: \\
\text { action }\end{array}$ & $\begin{array}{c}\text { Zone of use } \\
1: \\
\text { processed } \\
\text { material }\end{array}$ & $\begin{array}{c}\text { Zone of } \\
\text { use 2: } \\
\text { position }\end{array}$ & $\begin{array}{c}\text { Zone } \\
\text { of use } \\
2: \\
\text { action }\end{array}$ & $\begin{array}{c}\text { Zone of use } \\
\text { 2: } \\
\text { processed } \\
\text { material }\end{array}$ \\
\hline 13F397 & Quartz & 2 & 19 & $\mathrm{~T}$. & M.H. & 18 & $\mathrm{~T}$. & M.H. \\
\hline 15F364 & Quartz & 1 & 18 & I & M.H. & - & - & - \\
\hline $13 F 4144$ & Quartz & 1 & 18 & $\mathrm{~T}$. & $\mathrm{H}$. & - & - & - \\
\hline $13 \mathrm{~F} 22$ & Quartz & 1 & 07 & $\mathrm{P}$. & M.H. & - & - & - \\
\hline $13 \mathrm{E} 413$ & Quartz & 1 & 10 & $\mathrm{~T}$. & M.S. & - & - & - \\
\hline $13 F 3136$ & Quartz & 1 & 09 & $\mathrm{~L}$. & M.H. & - & - & - \\
\hline $13 \mathrm{~F} 430$ & Quartz & 1 & 20 & $\mathrm{~T}$. & S. & - & - & - \\
\hline $13 \mathrm{~F} 443$ & Quartz & 1 & 18 & L. & M.S. & - & - & - \\
\hline $13 \mathrm{~F} 427$ & Quartz & 1 & 10 & I & I & - & - & - \\
\hline 13E4121 & Quartz & 1 & 19 & L. & M.H. & - & - & - \\
\hline $13 F 2389$ & Quartz & 2 & 18 & I & M.S. & 08 & - & M.S. \\
\hline $13 E 4124$ & Quartz & 1 & 20 & $\mathrm{~T}$. & M.H. & - & - & - \\
\hline $13 F 337$ & Quartz & 1 & 20 & I.? & I & - & - & - \\
\hline
\end{tabular}

Most use-wear traces identified on this kind of artefacts can be attributed to the processing of medium-hard or medium-soft materials (Figure 11), with the exception of an artefact that demonstrate a transversal action on soft material.


Figure 11. Mousterian point from the Ciota Ciara cave showing use-wear traces due to the processing of medium-hard materials (on the left); non-retouched flake showing use-wear traces due to the processing of medium-soft materials. The scale bars to the lower left of each macroscopic image are $1 \mathrm{~cm}$ wide.

Concerning the use-wear traces identified on the edges of the retouched tools, a clear prevalence of medium-hard and hard materials' processing is evident but it is not possible to set a specific connection between tool's typology, kind of action and processed material 
(Arzarello et al. 2012b). These data corresponds to the analysis results carried out on coeval sites (Beyries 1987; Lemorini 2000).

About the unretouched flakes, the processing of medium-hard and hard materials is prevailing, even if two of them show use-wear traces referable to the processing of mediumsoft and soft materials.

The presence of just two artefacts, within the lithic assemblage of S.U. 13, each one showing two different zones of use, all referable to the processing of the same kind of material, highlights a poor versatility of lithic tools.

The use of quartz tools for the hard and medium-hard materials processing, although the poor mechanical resistance of this raw material, is probably due to its availability in the area nearby the site.

Finally, evaluating all of artefacts showing use-wear traces, it is evident a predominance of the processing of materials with hardness varying from medium-hard to medium-soft. According to Odell (1981), this hardness is related to such materials as soft wood, seasoned wood and deer antler.

A poor activity concerning the processing of carcasses is highlighted by the presence of both an impact fracture on the bi-convex convergent side-scarper and of two flakes showing use-wear traces, related to the processing of soft and medium-soft materials.

\section{Discussion}

Monte Fenera represents the most important evidence of the presence of Homo neanderthalensis in Piedmont.

The reopening, in 2009, of the systematic excavations at the Ciota Ciara cave has allowed to obtain new and interesting data concerning the first population of the Northwestern of Italy.

The palaeo-environmental reconstruction shows that the human settlement of the Ciota Ciara cave (S.U. 13 and 14) took place during OIS 5, in a temperate-humid period, with an environment characterized, especially, by deciduous woodland, as demonstrated by faunal remains (Arzarello et al. 2012a; 2012b).

The lithic assemblage reveals an "opportunistic" behaviour pattern: i.e. a strong adaptation to the characteristics of the raw materials available in the area (quartz and spongolite) for the production of lithic tools. The local raw materials were exploited through all the débitage methods typical of the Middle Palaeolithic (Boëda et al. 1990) but the reduction sequences are short and customized for local raw materials not particularly suitable for knapping.

Based on the characteristics of the lithic assemblage and on the use-wear analysis, in addition to the significant presence of Ursus spelaeus, we can conclude that the Ciota Ciara cave was occupied, time after time, for short periods, probably in summertime (Arzarello et al. 2012a; 2012b).

In conclusion, the data emerging from the interdisciplinary approach has allowed us to definitively criticize the theory of the "Alpine Mousterian" (Battaglia 1957; Lo Porto 1957), characterized by a lithic industry "rough and primitive" based on the lack of the Levallois method and of the limited number of retouched tools. The lithic industry from the Ciota Ciara cave proves that the limited number of retouched tools, in addition to the use of short reduction sequences for the production of lithic tools, is just the result of a technological behaviour extremely conditioned to the nature and availability of lithic raw materials (Arzarello et al. 2012b). 


\section{Acknowledgments}

Our work in the Ciota Ciara Cave have been made possible thanks to the collaboration and support of the Borgosesia municipality and the Soprintendenza per $i$ Beni Archeologici del Piemonte e del Museo di Antichità Egizie.

\section{References}

Arzarello, M., Fontana, F. \& Peresani, M. 2011, Manuale di tecnologia litica preistorica. Concetti, metodi e tecniche. Carocci Editore, Rome, 263 p. (in Italian) ("Lithic technology handbook. Concepts, methods and techniques")

Arzarello, M., Daffara, S., Berruti, G., Berruto, G., Bertè, D., Berto, C., Gambari, F.M. \& Peretto, C. 2012a, The Mousterian Settlement in the Ciota Ciara Cave: the Oldest Evidence of Homo neanderthalensis in Piedmont (Northern Italy). Journal of Biological Research, 85(1): 71-75. doi:10.4081/jbr.2012.4068

Arzarello, M., Daffara, S., Berruti, G., Berruto, G., Bertè, D., Berto, C. \& Peretto, C. 2012b, L'occupazione musteriana della grotta della Ciota Ciara. Quaderni della Soprintendenza Archeologica del Piemonte, 27: 331-336. (in Italian) ("The mousterian settlement of the Ciota Ciara cave")

Battaglia, R. 1957, Le ossa lavorate della Caverna Pocala nelle Venezia Giulia e il problema del Musteriano Alpino. Bullettino di Paleontologia italiana, 63: 5-15. (in Italian) ("Processed bones from Caverna Pocala (Venezia Giulia) and the problem of the Alpine Mousterian")

Berruti, G. \& Arzarello, M. 2012: L'analisi tracceologica per la ricostruzione delle attività nella preistoria: l'esempio della grotta della Ciota Ciara (Borgosesia - VC). Annali dell'Università di Ferrara. Museologia scientifica e naturalistica, 8(1): 117-125. (in Italian) ("The use-wear analysis for the reconstruction of prehistorical activities: the example of the Ciota Ciara cave (Borgosesia - VC)")

Beyries, S. 1987, Variabilité de l'Industrie Lithique du Moustérien: Approche Fonctionnelle sur Quelques Gisements Françaises. B.A.R. International Series Vol. 328. British Archaeological Reports, Oxford, 310 p. (in French) ("Variability of Mousterian lithic industry: functional approach to some French sites")

Boëda, E. 1993, Le débitage discoide et le débitage Levallois recurrent centripète. Bulletin de la Société Préhistorique Française, 90: 392-404. (in French) ("Discoid débitage and recurrent centripetal Levallois débitage") doi:10.3406/bspf.1993.9669

Boëda, E. 1994, Le concept Levallois : variabilité des méthodes. Monographie du CRA Vol. 9. CNRS Éditions, Paris, 280 p. (in French) ("The Levallois concept: variability of the methods")

Boëda, E., Geneste, J.-M. \& Meignen, L. 1990, Identification de chaine opératoire lithiques du Paléolithique ancien et moyen. Paleo, 2: 43-80. (in French) ("Identification of Middle and Lower Paleolithic reduction sequences") doi:10.3406/pal.1990.988

Bordes, F. 1961, Typologie du Paléolithique ancien et moyen. Publications de l'Institut de préhistoire de l'Université de Bordeaux Vol. 1. Delmas, Bordeaux, 85 p. (in French) ("Typology of the Lower and Middle Palaeolithic")

Busa, F., Gallo, L.M. \& Dellarole, E. 2005, L'attività di ricerca nelle grotte del Monte Fenera. In: D'acqua e di pietra. Il monte Fenera e le sue collezioni museali, (Fantoni, R., Cerri 
R. \& Dellarole, E., Eds.), Zeisciu Centro Studi, Magenta: p. 218-223. (in Italian) ("Researches within the caves of Monte Fenera")

Cliquet, D. 2007, Approvisionnement en matieres premieres lithique et vegetales, et en resources alimentaires en Normandie (France) entre le stade 7 et le stade 3. In: Aires d'approvisionnement en matières prémieres et aires d'approvisionnement en resources alimentaires/Raw Material Supply Areas and Food Supply Areas, (Moncel, M.-H., Moigne, A.-M., Arzarello, M. \& Peretto, C., Eds.), B.A.R. International Series Vol. 1725, Archaeopress, Oxford: p. 93-102. (in French) ("Supply areas of lithic and organic raw materials and of food resources in Normandy (France) between OIS 7 and OIS 3")

Depaepe, P. 2007, L'approvisionnement en matieres premieres lithiques en France septentrionale au Paleolithique moyen recent. In: Aires d'approvisionnement en matières prémieres et aires d'approvisionnement en resources alimentaires, (Moncel, M.-H., Moigne, A.-M., Arzarello, M. \& Peretto, C., Eds.), B.A.R. International Series Vol. 1725, Archaeopress, Oxford: p. 87-92. (in French) ("Supply areas of lithic raw materials in northen France during the late Middle Paleolithic")

Fantoni, R., Barbieri, C., Bini, A., Bistacchi, A., Ceriani, A., Cossutta, F., Decarlis, A., Di Giulio, A., Ghielmi, M., Mancin, N., Rogledi, S. \& Zattin, M. 2005a, Tra Alpi e Pianura Padana: l'evoluzione recente del margine alpino - padano in bassa Valsesia. In: D'acqua e di pietra. Il monte Fenera e le sue collezioni museali, (Fantoni, R., Cerri R. \& Dellarole, E., Eds.), Zeisciu Centro Studi, Magenta: p. 130-142. (In Italian) ("Between Alps and Po Valley: recent evolution of the alpine-Po margin in Valsesia")

Fantoni, R., Decarlis, A. \& Fantoni, R. 2005b, Geologia del Monte Fenera. In: D'acqua e di pietra. Il monte Fenera e le sue collezioni museali, (Fantoni, R., Cerri R. \& Dellarole, E., Eds.), Zeisciu Centro Studi, Magenta: p. 86-91. (in Italian) (“Geology of Monte Fenera")

Fedele, F. 1966, La stazione paleolitica del Monfenera (Borgosesia). Rivista di Studi Liguri, 32: 5-105. (in Italian) ("The palaeolithic site of Monfenera (Borgosesia)")

Fedele, F. 1984-85, Il Paleolitico in Piemonte: Le Alpi Occidentali. Ad Quintum Archeologia del Nord-Ovest, 7: 23-44. (in Italian) ("The Palaeolithic of Piedmont: the western Alps")

Forestier, H. 1993, Le Clactonien: Mise en application d'une nouvelle méthode de débitage s'inscrivant dans la variabilité des systèmes de production lithique du Paléolithique ancient. Paleo, 5: 53-82. (in French) ("The Clactonian: application of a new knapping method falling within the variability of Lower Paleolithic reduction sequences") doi: $10.3406 / \mathrm{pal} .1993 .1104$

van Gijn, A.L. 1989, The wear and tear of flint: principles of functional analysis applied to Dutch Neolithic assemblages. Analecta praehistorica Leidensia Vol. 22. University of Leiden, Institute of Prehistory, Leiden, $181 \mathrm{p}$.

Huet, B. 2007, Les industries a composante lithologique mixte au Paleolithique moyen dans le massif armoricain (France): mise en evidence d'un comportement economique spécifique. In: Aires d'approvisionnement en matières prémieres et aires d'approvisionnement en resources alimentaires/Raw Material Supply Areas and Food Supply Areas, (Moncel, M.-H., Moigne, A.-M., Arzarello, M. \& Peretto, C., Eds.), B.A.R. International Series Vol. 1725, Archaeopress, Oxford: p.103-112. (in French) ("Middle Paleolithic lithic industries of the Armoricain massif (France): highlighting of a specific economical behaviour") 
Keeley, L.H. 1980, Experimental determination of stone tool uses: a microwear analysis. Prehistoric archeology and ecology. University of Chicago Press, Chicago, 212 p.

Lemorini, C. 2000, Reconnaître des tactiques d'exploitation du milieu au Paléolithique moyen. La contribution de l'analysefonctionnelle. Étude fonctionnelle des industries lithiques de Grotta Breuil (Latium, Italie) et de la Combette (Bonnieux, Vaucluse, France). B.A.R. International Series Vol. 858, Archaeopress, Oxford, 142 p. (in French) ("Middle Paleolithic environmental exploitation. The contribution of the use-wear analysis. Use-wear analysis of Grotta Breuil (Italy) and la Combette (France) lithic assemblages")

Lo Porto, F.G. 1957, Tracce del "Musteriano Alpino" in una grotta del Monfenera, presso Borgosesia. Rivista di Studi Liguri, 23(3-4): 286-293. (in Italian) ("Signs of the Alpine Mousterian in a cave from Monfenera - Borgosesia")

Mourre, V. 1996, Les industries en quartz au Paléolithique. Terminologie, méthodologie et technologie. Paléo, 8: 205-223. (in French) ("Quartz lithic industries during the Paleolithic. Terminology, methodology and technology") doi:10.3406/pal.1996.1160

Odell, G.H. 1981, The mechanism of use-breakage of stone tools: Some testable hypotheses. Journal of field archaeology, 8(2): 197-209. doi:10.1179/009346981791505120

Owen, W. 1938, The Kombewa Culture, Kenya colony. Man, 38: 203-205. Stable URL: http://www.jstor.org/stable/2791552

Pignat, G. \& Plisson, H. 2000, Le quartz, pour quel usage? L'outillage mésolithique de Vionnaz (Suisse) et l'apport de la tracéologie. In: Actes de la Table Ronde "Épipaléolithique et Mésolithique”, Lausanne, 21-23 novembre 1997 (Crotti, P., Ed.), Cahiers d'Archéologie romande Vol. 81, Musée Cantonal d'Archéologie et d'Histoire, Lausanne: p. 65-78. (in French) ("Quartz, which use? The Mesolithic lithic assemblage of Vionnaz (Switzerland) and the use-wear analysis contribution")

Semenov, S.A. 1964, Prehistoric technology: an experimental study of the oldest Tools and Artefacts from traces of Manufacture and Wear. Cory, Adams \& Mackay, London, $211 \mathrm{p}$.

Strobino, F. 1981, Preistoria in Valsesia: studi sul Monte Fenera. Editrice Zanfa, Varallo, 89 p. (in Italian) ("Valsesia Prehistory: studies about Monte Fenera")

Strobino, F. 1992, Nota sulla cronistoria delle ricerche sul Monte Fenera dalle origini agli anni Sessanta: prospettive per le future indagini. De Valle Sicida, 3: 7-14. (in Italian) ("Chronicle of the research at Monte Fenera from the origins till the Sixties: perspectives for further investigations")

Sussman, C. 1985, Microwear on Quartz Tools: Fact or Fiction? World Archaeology, 17(1): 101-111. doi: $10.1080 / 00438243.1985 .9979953$

Vaquero, M. 2007, Preface. In: Aires d'approvisionnement en matières premières et aires d'approvisionnement en ressources alimentaires/Raw Material Supply Areas and Food Supply Areas, (Moncel, M.-H., Moigne, A.-M., Arzarello, M. \& Peretto, C. Eds.), B.A.R. International Series Vol. 1725, Archaeopress, Oxford: p. 3-4. 